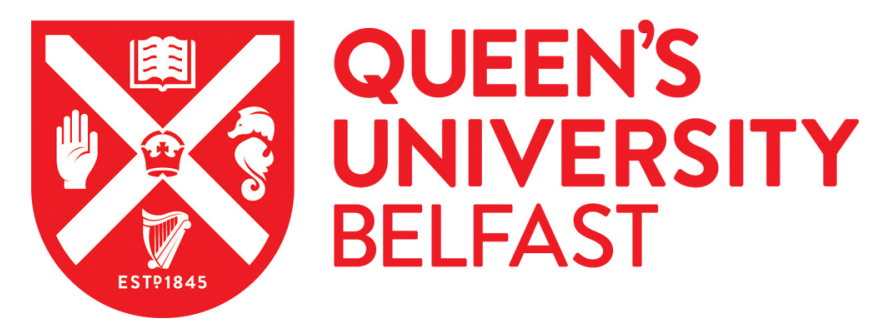

\title{
Evaluation of the efficacy of multiple physical, biological and natural antimicrobial interventions for control of pathogenic Escherichia coli on beef
}

Stratakos, A. C., \& Grant, I. R. (2018). Evaluation of the efficacy of multiple physical, biological and natural antimicrobial interventions for control of pathogenic Escherichia coli on beef. Food Microbiology, 76, 209-218. https://doi.org/10.1016/j.fm.2018.05.011

Published in:

Food Microbiology

\section{Document Version:}

Peer reviewed version

Queen's University Belfast - Research Portal:

Link to publication record in Queen's University Belfast Research Portal

\section{Publisher rights}

Copyright 2018 Elsevier.

This manuscript is distributed under a Creative Commons Attribution-NonCommercial-NoDerivs License

(https://creativecommons.org/licenses/by-nc-nd/4.0/), which permits distribution and reproduction for non-commercial purposes, provided the author and source are cited.

\section{General rights}

Copyright for the publications made accessible via the Queen's University Belfast Research Portal is retained by the author(s) and / or other copyright owners and it is a condition of accessing these publications that users recognise and abide by the legal requirements associated with these rights.

\section{Take down policy}

The Research Portal is Queen's institutional repository that provides access to Queen's research output. Every effort has been made to ensure that content in the Research Portal does not infringe any person's rights, or applicable UK laws. If you discover content in the

Research Portal that you believe breaches copyright or violates any law, please contact openaccess@qub.ac.uk. 
4 Evaluation of the efficacy of multiple physical, biological and natural 5 antimicrobial interventions for control of pathogenic Escherichia coli on beef

6

7 Alexandros Ch. Stratakos ${ }^{\dagger}$ and Irene R. Grant*

8

9 Institute for Global Food Security, School of Biological Sciences, Queen's University Belfast, 10 Belfast, UK

11

12 († Current address: Food Microbiology Branch, Agriculture, Food and Environmental Science 13 Division, Agri-Food and Biosciences Institute for Northern Ireland, Belfast, UK)

${ }^{*}$ Correspondence to:

16 Dr Irene R. Grant

17 Institute for Global Food Security

18 School of Biological Sciences

19 Queen's University Belfast

2097 Lisburn Road,

21 Belfast BT9 7BL, UK.

22 E-mail: i.grant@qub.ac.uk 
Antimicrobial effects of multiple physical, biological and natural interventions on pathogenic

Escherichia coli in raw beef were assessed. A cocktail of $E$. coli strains was inoculated onto gamma-irradiated beef and enumerated immediately after each intervention and during storage at $4^{\circ} \mathrm{C}$ for 7 days. Of the physical interventions, silver-containing antimicrobial packaging and ozone gas treatment did not show significant antimicrobial effects, however cold plasma treatment reduced $E$. coli levels by 0.9 and $1.82 \log _{10} \mathrm{CFU} / \mathrm{cm}^{2}$ after 2 and 5 min treatments, respectively. A phage cocktail reduced E. coli counts by 0.63 and $1.16 \log _{10}$ $\mathrm{CFU} / \mathrm{g}$ after $24 \mathrm{~h}$ storage at 4 and $12^{\circ} \mathrm{C}$, respectively. Of the natural interventions, vinegar and lactic acid $(5 \%)$ washes for 5 min caused reductions of $\sim 1 \log _{10}$ CFU/g immediately after treatment, whereas lactoferrin and nisin treatments, separately or in combination, had insignificant antimicrobial effects. Nanoemulsions containing carvacrol or thyme essential oils caused immediate E. coli reductions of 1.41 and $1.36 \log _{10} \mathrm{CFU} / \mathrm{g}$, respectively, plus a progressive reduction in viable numbers during storage at $4^{\circ} \mathrm{C}$. Our findings suggest that cold plasma, bacteriophages, vinegar, lactic acid, or carvacrol and thyme essential oil nanoemulsions could potentially be of use to the beef industry for controlling pathogenic $E$. coli contamination.

Keywords: Escherichia coli O157:H7, decontamination, beef, cold plasma, bacteriophages essential oil nanoemulsions. Foodborne illness is a major concern for industry, public authorities and consumers, with the global impact reaching 600 million cases and 420,000 deaths on an annual basis (World Health Organisation, 2015). Over the past few decades, the food producing sector has been experiencing an increase in the demand for meat products. Nevertheless, the meat sector has also been found to be the least trusted by consumers, probably due to the increase in 
Misra and Jo, 2017). Escherichia coli 0157 is considered a worldwide health threat and is

57 the serogroup of E. coli most commonly associated with illnesses and deaths in humans (Scallan et al., 2011); with clinical manifestations ranging from abdominal pain and diarrhoea to potentially fatal haemolytic-uraemic syndrome (Food Standards Agency, 2014). Although many food products have been implicated in foodborne outbreaks, foods of bovine origin are the most frequently reported as vehicles for human E. coli 0157 infection (European Food Safety Authority, 2011). Initial E. coli O157 contamination of beef products occurs mainly at the de-hiding stage of slaughtering because of bacterial transfer and adherence to the carcasses (Chagnot et al., 2013). Hazard analysis and critical control point systems have been introduced in many countries aiming to reduce or eradicate these pathogens, but even with these systems in place, the absence of $E$. coli $O 157$ from meat cannot be guaranteed and there are still outbreaks of this pathogen that can be traced back to beef and beef products. Due to the potential meat safety concerns, researchers and the industry are continuously investigating different strategies to tackle this issue. The use of antimicrobial interventions on animal tissues with the use of hot water washing and steam pasteurization, organic acids, chlorine dioxide trisodium phosphate and cetylpyridinium chloride has been extensively studied (Mohan and Pohlman, 2016). However, the frequent foodborne disease outbreaks associated with ground beef necessitates further research. Organic acids have been approved for meat decontamination in the United States (USDA Food Safety and Inspection Service, 1996) and in 2013 lactic acid was approved for decontamination of beef carcasses by the European Commission (2013). Thermal treatments have been found to be effective in inactivating pathogenic E. coli and other pathogens; however they can also result in unwanted physical and chemical changes. Non-thermal processing technologies have also been investigated as substitutes for thermal processes to reduce microbial contamination while increasing quality and nutrient retention (Wheeler et al., 2014). Food irradiation, specifically electron-beam irradiation, has been found to significantly reduce $E$. coli $\mathrm{O} 157$ on beef, without negative effects on the sensory characteristics of the meat (Arthur et al., 2005). However, negative consumer opinion regarding food irradiation hinders its 
widespread adoption. Ultraviolet radiation and ozone treatments are also of interest to the meat industry since they do not result in chemical residues or damage (Khadre et al., 2001). High pressure processing (HPP) is another non-thermal technology with high antimicrobial efficacy which has been gaining increasing importance and has been used under commercial conditions in many countries (Patterson, 2005; Hsu et al., 2015). HPP in a range 400-600 MPa has been shown to be effective in controlling most major foodborne pathogenic bacteria (e.g. E. coli O157:H7, Salmonella spp.) present in meat products such as beef and ground chicken, but is can also cause detrimental changes in meat quality (Chien et al., 2016). Among the non-thermal technologies, the application of cold plasma to improve the microbiological safety and quality of meat and meat products is very new. A few recent studies have demonstrated the potential of cold plasma technology as a novel intervention for ensuring the safety of ready-to-eat beef jerky, chicken and pork (Dirks et al., 2012; Kim et al., 2013; Kim et al., 2014). Essential oils have also been gaining importance as food preservatives, since many studies have found that they possess significant antimicrobial properties against a broad range of foodborne pathogens (Zhang et al., 2016). The antimicrobial efficiency of the essentials oils has been attributed to the high content of phenolic compounds they possess, such as carvacrol, eugenol and thymol, which can also be extracted, isolated and used as food antimicrobials (Burt, 2004). Furthermore, many studies have shown that the concept of combined decontamination treatments (hurdle approach) could be a more efficient strategy for reducing or eliminating pathogens than the application of single interventions (Sofos, 2005).

The aim of this study was to assess and compare the antimicrobial effects of different non-thermal physical (antimicrobial packaging, cold plasma, and ozone), biological (bacteriophages) and natural (vinegar, lactic acid, encapsulated essential oils, lactoferrin and nisin) interventions, as well as combinations of some treatments, against pathogenic $E$. coli present on beef cuts. The effect on E. coli was determined immediately after application of each intervention and throughout a 7 -day storage period at refrigeration $\left(4^{\circ} \mathrm{C}\right)$, and in some cases mild abuse $\left(12^{\circ} \mathrm{C}\right)$ temperatures, after vacuum packaging. 


\section{Materials and methods}

114

\subsection{Bacterial strains used and inoculum preparation}

A cocktail of four E. coli strains was used for inoculation of beef samples. This cocktail consisted of three E. coli strains, ATCC BAA 1427, ATCC BAA 1428 and ATCC BAA 1429, designated by the USDA Food Safety and Inspection Service (2015) as surrogate indicator organisms for E. coli O157, and a fourth E. coli strain, NCTC 12900, which is a shigatoxin negative serotype $\mathrm{O} 157: \mathrm{H} 7$ strain. For each strain a loopful of a fresh Tryptone soya agar plus $0.6 \%$ yeast extract (TSAYE, both Oxoid Limited, Basingstoke, UK) slope culture was inoculated into $10 \mathrm{ml}$ of Brain heart infusion broth (BHI, Oxoid) and incubated at $37^{\circ} \mathrm{C}$ for $24 \mathrm{~h}$. Subsequently, $100 \mu \mathrm{l}$ of a $10^{-4}$ dilution of this broth culture in maximum recovery diluent (Oxoid), was inoculated into another $10 \mathrm{ml} \mathrm{BHI}$ broth and incubated at $37^{\circ} \mathrm{C}$ for $24 \mathrm{~h}$, until the stationary phase of growth was reached. The final $10 \mathrm{ml}$ cultures were harvested by centrifuging at $3600 \times \mathrm{g}$ for $30 \mathrm{~min}$, washed twice in phosphate-buffered saline (PBS), and the pellet re-suspended in a final volume of $10 \mathrm{ml}$ PBS to give approximately $10^{8}-10^{9} \mathrm{CFU} / \mathrm{ml}$. To produce the $E$. coli cocktail, equal volumes of suspensions of the four separate strains were combined and mixed well.

\subsection{Preparation and inoculation of beef samples}

Bulk packs $(10 \mathrm{~kg})$ of beef cuts were obtained from a local producer. Before use in challenge studies, rectangular beef cuts (approx. $5 \mathrm{~cm} \times 5 \mathrm{~cm}$ ) were aseptically weighed as $25 \mathrm{~g} \pm 0.2 \mathrm{~g}$ samples into stomacher bags and sterilised by gamma radiation (15 kGy dose) at a nearby ${ }^{60} \mathrm{Co}$ Gamma beam 650 facility, in order to inactivate any naturally occurring $E$. coli cells. Irradiated beef samples were kept frozen at $-20^{\circ} \mathrm{C}$ until required for experiments.

The E. coli cocktail was spot inoculated $(250 \mu \mathrm{l})$ onto the surface of irradiated beef samples, to simulate surface contamination with faeces (McCann et al., 2006). The final inoculum level was approximately $5 \log _{10} \mathrm{CFU} / \mathrm{g}$ or $\mathrm{CFU} / \mathrm{cm}^{2}$. Inoculated, unpackaged beef 
samples were stored at $4^{\circ} \mathrm{C}$ for 1 hour before application of the antimicrobial intervention

141 (Poimenidou et al., 2016). After application of each intervention, beef samples were vacuum

142 packed, using a FoodSaver ${ }^{\circledR}$ vacuum sealing system and associated bags (Sunbeam

143 Products, Inc., Boca Raton, USA), before storage at $4^{\circ} \mathrm{C}$ (and $12^{\circ} \mathrm{C}$ in certain cases only) for

1447 days; samples were tested for viable E. coli at day $0,1,3,5$ and 7 . Samples were stored at

$1454^{\circ} \mathrm{C}$ as this is the storage temperature used by the beef industry.

\subsection{Antimicrobial interventions}

The antimicrobial effects of a range of different physical, biological and natural antimicrobial interventions were studied. The specific concentrations or processing conditions employed for each intervention were selected on the basis of relevant previously published studies and/or preliminary trials.

\subsubsection{Physical interventions}

To investigate the effect of antimicrobial packaging, a commercial antimicrobial polyethylene terephthalate film incorporating silver nanoparticles (kindly provided by LINPAC Packaging, Featherstone, UK) was used to wrap the meat before vacuum packing using a conventional film. Control samples were vacuum packed using a conventional food grade film.

To investigate the effect of cold plasma treatment, a dielectric barrier discharge cold plasma jet, as described by Alkawareek et al. (2012), was used. Briefly, the plasma source consisted of a quartz dielectric tube with an inner diameter of $4 \mathrm{~mm}$ and an outer diameter of $6 \mathrm{~mm}$ and it operated at voltage amplitude of $6 \mathrm{kV}$ and a repetition frequency of $20 \mathrm{kHz}$. The plasma jet configuration was encased in solid acrylic tubing. The plasma jet was produced using a mixture of helium $(99.5 \%)$ and oxygen $(0.5 \%)$ at flow rate of 2 standard litres per min. The temperature of the produced plume was $39^{\circ} \mathrm{C}$. Beef samples were placed on a Petri dish at a distance of $15 \mathrm{~mm}$ from the plasma source during treatment. 
they showed promising antimicrobial activity without affecting the organoleptic properties of the beef. An untreated control (no exposure to plasma) was also tested. After treatment, beef samples were vacuum packed and stored under refrigeration $\left(4^{\circ} \mathrm{C}\right)$.

Ozone was applied to beef samples as a gaseous treatment in a hermetically closed transparent cylinder. Ozone was generated using an ozone generator (ESCO, Labozone model, UK). Two ozone concentrations were tested $\left(7.2\right.$ and $\left.32 \mathrm{~g} \mathrm{O}_{3} / \mathrm{m}^{3}\right)$ with an exposure time of $5 \mathrm{~min}$ in both cases. Ozone concentration was recorded using an ozone gas analyzer (GM-6000-OEM Ozomat, Germany). An untreated control was also tested.

\subsubsection{Biological intervention}

A commercially available bacteriophage cocktail (EcoShield ${ }^{\mathrm{TM}}$, Intralytix, USA) against $E$. coli $\mathrm{O} 157$ was purchased for this study. The bacteriophage cocktail contained three lytic phages (ECML-4, ECML-117, and ECML-134) belonging to the family Myoviridae. Phage cocktail stocks were stored at $4^{\circ} \mathrm{C}$ in deionised water, according to manufacturer's instructions, and enumerated by the soft agar overlay method (Jamalludeen et al., 2007). The phage cocktail $(250 \mu \mathrm{l})$ was spread onto the beef surface to achieve a multiplicity of infection (MOI) of 1000; this $\mathrm{MOI}$ was shown to yield the most promising results during preliminary trials (results not shown). For untreated controls, $250 \mu$ of PBS was used instead. The phage preparation was added on the same surface of the beef sample that the E. coli cells had previously been inoculated on. Samples treated with the bacteriophage cocktail were also stored at $12^{\circ} \mathrm{C}$ as studies have shown that higher storage temperatures might affect pathogen survival (e.g. Viazis et al., 2011). This mild abuse temperature was included in order to elucidate this potential effect of phage action.

\subsubsection{Natural interventions}

The natural antimicrobial interventions applied to beef are summarised in Table 1. Beef samples were immersed in a $1 \mathrm{~L}$ antimicrobial solution in all cases. Preliminary trials were conducted in order to identify appropriate exposure times and concentrations. Results 
showed that 5 min immersion was promising and was followed or not by $30 \mathrm{~s}$ rinsing in sterile water. Vinegar (6\% vol/vol acetic acid) purchased from a local supermarket was used undiluted. A 5\% (vol/vol) lactic acid (Sigma-Aldrich, Dorset, UK) solution in sterile water was also tested. A nisin solution (Sigma-Aldrich, $1000 \mathrm{IU} / \mathrm{ml}$ ) was also prepared according to Boziaris \& Nychas (2006), and bovine lactoferrin (Sigma-Aldrich) at a final concentration of $0.5 \mathrm{mg} / \mathrm{ml}$. The combination of lactic acid $(5 \%)$ and nisin $(1000 \mathrm{IU} / \mathrm{ml})$ or lactoferrin $(0.5$ $\mathrm{mg} / \mathrm{ml})$ and nisin $(1000 \mathrm{lU} / \mathrm{ml})$ was also investigated against $E$. coli by sequential immersion in each of the solutions for 5 min. Physically stable nanoemulsions loaded with carvacrol and thyme oil were also prepared using the spontaneous emulsification method (Chang et al., 2013). Specifically, the preparation was as follows: $4 \mathrm{~g}$ carvacrol (Sigma-Aldrich) or thyme essential oil (Sigma-Aldrich) were added to $6 \mathrm{~g}$ medium chain triglyceride oil (Miglyol 812, IOI Oleo, Germany) and mixed for 5 min (600 rpm). Subsequently, $10 \mathrm{~g}$ Tween 80® (SigmaAldrich) was added to the oil mixture and mixed for another 5 min. The Tween 80/oil mixture $(20 \mathrm{~g})$ was titrated $(2 \mathrm{~mL} / \mathrm{min})$ into $80 \mathrm{~g} 5.0 \mathrm{mM}$ sodium citrate buffer (pH 3.5) and was mixed at $600 \mathrm{rpm}$ for $15 \mathrm{~min}$. Subsequently, the emulsion was sterilized by passing through a sterile $0.22 \mu \mathrm{m}$ syringe filter and stored in sterile $50 \mathrm{~mL}$ tubes at $4^{\circ} \mathrm{C}$. Droplet size was measured using dynamic light scattering (Zetasizer Nano ZS, Malvern Instruments, UK). A water wash at room temperature $\left(20^{\circ} \mathrm{C}\right)$ was also used as an additional control treatment.

\subsection{Enumeration of E. coli on beef samples}

Vacuum packed beef samples were opened aseptically, and the contents were transferred to a sterile stomacher bag. A $10^{-1}$ dilution of the sample was prepared in Maximum recovery diluent (MRD, Oxoid). The dilution was homogenised for $1 \mathrm{~min}$ and when necessary further 10 fold dilutions were prepared. An aliquot of $1 \mathrm{ml}$ of each of the 10 fold dilutions was pour plated using Rapid 2 agar (Bio-Rad, Watford, UK) and enumerated after incubation at $37^{\circ} \mathrm{C}$ for $24 \mathrm{~h}$. Each sample was plated out in duplicate. With regards to the enumeration of surviving $E$. coli $\mathrm{O} 157$ cells after bacteriophage treatment, enumeration was performed as above but with the addition of a virucide (Jassim et al., 1998). The inclusion of 
224 the virucide (7 parts $10 \mathrm{mM}$ ferrous sulphate/3 parts tea extract) in the stomacher bags when

225 homogenizing beef samples prevented the overestimation of the phage killing effect due to 226 previously unbound phage particles coming into contact with surviving $E$. coli bacteria during 227 the homogenization process.

\subsection{Statistical analysis}

230 Each individual experiment was replicated on two different occasions, with three replicates included on each occasion. Data for pathogen counts were subjected to analysis of variance (ANOVA) to compare the interactions between treatment and storage time. Differences between effects were assessed by the Tukey test $(P<0.05)$.

\section{Results and Discussion}

\subsection{Physical interventions}

Different nanocomposite materials have been developed for antimicrobial packaging applications based on the incorporation and/or coating of nanoparticles (NPs) into/onto synthetic polymers. Previous studies performed on food products have demonstrated that incorporation of silver NPs into packaging films significantly extends the shelf-life of chicken meat, fruits and cheese (Costa et al. 2011; Incoronato et al. 2011; Azlin-Hasim et al. 2015). However, there appears to be a lack of studies on beef to date. In this study, a commercially available antimicrobial packaging (polyethylene terephthalate) with incorporated silver NPs was studied. Figure $1 \mathrm{~A}$ presents the effect of the antimicrobial packaging in comparison to a conventional food grade packaging film (control) during refrigerated storage. The $E$. coli counts for the samples remained stable during storage, as expected, since this pathogenic bacterium will not grow at a temperature below $8^{\circ} \mathrm{C}$ (Rajkowski and Marmer, 1995). Vacuum packaging using the antimicrobial film resulted in a

250 reduction in E. coli of approximately $0.6 \log _{10} \mathrm{CFU} / \mathrm{g}$, after 3 days of storage (Fig. 1A), with 251 the counts remaining stable throughout the remainder of the $7 \mathrm{~d}$ storage period. 
252 Sadeghnejad et al. (2014) developed films with silver nanoparticles and found that they were 253 effective in inhibiting E. coli growth in vitro. Damm et al. (2008) found that PA-6 films with $2541.9 \%(\mathrm{w} / \mathrm{w})$ of nanosilver incorporated into them reduced $E$. coli levels by approx. $0.5 \log _{10}$ $\mathrm{CFU} / \mathrm{ml}$ after $24 \mathrm{~h}$ at room temperature in vitro. Our results show that antimicrobial packaging did not reduce the $E$. coli counts significantly during storage of beef at $4^{\circ} \mathrm{C}$. In a previous study, Stratakos et al. (2015) demonstrated that the efficacy of antimicrobial packaging for chicken meat could be improved if applied in combination with additional hurdles. However, no combination treatments were studied during the study being reported here.

Cold plasma consists of reactive species such as reactive oxygen and nitrogen species, UV radiation, energetic ions, and charged particles (Han et al. 2016). The effectiveness of cold plasma decontamination depends on a plethora of factors which include the type of cold plasma generation device, the type of microorganism characteristics, the surface topography $\mathrm{sec}, 1 \mathrm{~min}, 2 \mathrm{~min}, 5 \mathrm{~min}, 10 \mathrm{~min}$ ) for beef decontamination (results not presented). Exposure times shorter that 2 min did not have any significant effect on the levels of $E$. coli, so the longer treatment times were used. Exposure to cold plasma for 2 min resulted in an immediate significant reduction $(P<0.05)$ in $E$. coli counts by $0.9 \log _{10} \mathrm{CFU} / \mathrm{cm}^{2}$, and a further reduction in viable numbers was observed over the course of 7 days storage (Figure 1B); there were significant differences between the $E$. coli counts in beef at day 1 and counts at days $3(P<0.05), 5(P<0.05)$ and $7(P<0.05)$ days storage. At the end of the 7 day storage E. coli counts had reduced by $2.28 \log _{10} \mathrm{CFU} / \mathrm{cm}^{2}$ in total. The $5 \mathrm{~min}$ cold plasma treatment resulted in a larger initial reduction in E. coli $\left(1.82 \log _{10} \mathrm{CFU} / \mathrm{cm}^{2}\right)$ compared to the 2 min treatment $(P<0.05)$, and also a significant $(P<0.05)$ progressive reduction in $E$. coli counts over the 7 days of storage; overall reduction after 5 min cold plasma treatment was 
$2.48 \log _{10} \mathrm{CFU} / \mathrm{cm}^{2}$ at the end of storage. Similar results were reported by Ulbin-Figlewicz et al. (2015) using a helium cold plasma source. After a 5 and 10 min treatment a reduction of 1.01 and $2.09 \log _{10} \mathrm{CFU} / \mathrm{cm}^{2}$ was achieved on the levels of E. coli on beef. Ziuzina et al. (2012) found that cold plasma treatment at $70 \mathrm{kV}$ for 2 min reduced E. coli, Salmonella, and Listeria monocytogenes on cherry tomatoes by approximately 3,6 and $7 \log _{10}$ CFU/sample, respectively, whereas a 5 min treatment was needed to reduce these pathogenic bacteria on strawberries by around $4 \log _{10}$ CFU/sample. One explanation for the progressive reduction in the levels of $E$. coli observed during storage after cold plasma treatment is that the reactive species generated are able to impart their antimicrobial effect for an extended period of time. However, these reactive species are short-lived and react immediately with the microbial cell. Therefore, this phenomenon of extended action could potentially be attributed to the occurrence of cells sub-lethally injured by cold plasma treatment, which during storage at a non-favourable temperature $\left(4^{\circ} \mathrm{C}\right)$ (cold storage acts as an additional hurdle against the pathogen), are unable to repair themselves and eventually die. Our results indicate that cold plasma could potentially be used to decrease the risk of pathogenic $E$. coli in beef and that increasing the exposure time would significantly enhance the decontamination effect of the treatment. Although, no visible changes were observed in the beef after the cold plasma treatments, it would be necessary to investigate any potential negative effects on beef quality attributes.

Ozone was studied due to its recognised antimicrobial use in the fresh produce industry (Greene et al. 2012). Ozone was applied to E. coli inoculated beef samples in gaseous form in an enclosed chamber. Two ozone concentrations were tested (7.2 and $32 \mathrm{~g}$ $\mathrm{O}_{3} / \mathrm{m}^{3}$ or $3400 \mathrm{ppm}$ and $15000 \mathrm{ppm}$, respectively) for an exposure time of $5 \mathrm{~min}$. Neither of the ozone treatments was able to cause a significant antimicrobial effect against $E$. coli either immediately after treatment or during storage (approx. reductions of $0.2-0.3 \log _{10}$ CFU/g, results not shown). Coll Cárdenas et al. (2011) found that treating beef samples with gaseous ozone only resulted in a decrease of $0.7 \log _{10} \mathrm{CFU} / \mathrm{g}$ in $E$. coli levels after $24 \mathrm{~h}$ exposure. McMillin and Michel (2000), working with ozonized minced beef inoculated 
with E. coli, showed that as ozone concentrations increased (500, 3500 and $5000 \mathrm{ppm}$ ) larger reductions of $E$. coli were achieved, reaching a maximum reduction of $2.0 \log _{10}$ CFU/g. The lack of any significant antimicrobial effect of ozone in this study could be attributed to the suppression of ozone efficiency by the presence of organic material on the beef surfaces. Since ozone can oxidize components of bacterial cells, it would also be able to oxidise any lean or adipose tissue present (Castillo et al., 2003). Güzel-Seydim et al. (2004) demonstrated that suspensions of locust bean gum, sodium caseinate and whipping cream actually protected E. coli and Staphylococcus aureus against ozone treatment effects. The results indicate the inadequacy of gaseous ozone processing, under the conditions tested during this study, to reduce the risk of E. coli on beef. The application of ozonated water could possibly be investigated as a potential alternative to gaseous ozone as it has shown promising results with foods of plant origin (Selma et al., 2008; Wani et al., 2015).

\subsection{Biological intervention}

The effectiveness of a commercially available bacteriophage cocktail (EcoShield ${ }^{\mathrm{TM}}$ ) in controlling the growth of $E$. coli $\mathrm{O} 157$ inoculated in raw beef was investigated. Only $E$. coli O157 strain NCTC 12900 was used to inoculate beef samples for the bacteriophage experiments; because the phage cocktail would not infect the other surrogate $E$. coli strains used as the inoculum when studying other interventions. Figure 2 presents the levels of $E$. coli $\mathrm{O} 157$ during refrigerated storage $\left(4^{\circ} \mathrm{C}\right)$ and at a mild abuse storage temperature $\left(12^{\circ} \mathrm{C}\right)$. Enumeration of surviving E. coli 0157 cells was conducted with the inclusion of a virucide (Jassim et al., 1998; Chibeu et al., 2013) when stomaching the samples in order to inactivate unbound phages. This approach was taken to avoid overestimation of the phage antimicrobial effect due to previously unbound phage particles coming into contact with surviving bacteria during the stomaching process. The $\mathrm{MOI}$ is an important parameter influencing the effectiveness of bacteriophage treatment, as higher MOls increase likelihood of individual bacteria contacting phages. A preliminary trial with beef samples showed that a MOI of 1000 was necessary to reduce counts of the pathogen. Kudva et al. (1999) also 
demonstrated that a $\mathrm{MOI}$ of at least 1000 for lytic phages was needed to reduce numbers of

337 E. coli $\mathrm{O} 157$ in broth culture at $4^{\circ} \mathrm{C}$.

338 During the 7 day storage, E. coli counts for untreated (control) beef samples stored at $4^{\circ} \mathrm{C}$ remained stable, whereas for the untreated (control) samples stored at $12^{\circ} \mathrm{C} \mathrm{E}$. coli O157 counts increased from around $5 \log _{10} \mathrm{CFU} / \mathrm{cm}^{2}$ at the beginning of storage to 7.81 $\log _{10} \mathrm{CFU} / \mathrm{cm}^{2}$ after 7 days. Treatment of beef with the phage cocktail significantly reduced the E. coli counts after $24 \mathrm{~h}$ storage ( $\mathrm{P}<0.05)$; a $0.63 \log _{10} \mathrm{CFU} / \mathrm{cm}^{2}$ reduction was observed for samples stored at $4^{\circ} \mathrm{C}(\mathrm{P} 4)$ after $24 \mathrm{~h}$ (Fig. 2). A further progressive reduction in E. coli counts was also observed during storage reaching an overall $1.53 \log _{10}$ reduction after 7 days. Notably, after the first $24 \mathrm{~h}$, the counts for the phage-treated beef samples stored at $4^{\circ} \mathrm{C}$ were always lower $(P<0.05)$ than control samples $(C 4)($ Fig. 2$)$. For samples stored at the mild abuse temperature a more pronounced decrease in the pathogen counts was observed. After $24 \mathrm{~h}$ the $\mathrm{E}$. coli counts of phage-treated beef samples stored at $12^{\circ} \mathrm{C}$ (P12) counts were reduced by $1.16 \log _{10}$; almost twice as much as the decrease observed for phage-treated beef stored at $4^{\circ} \mathrm{C}(\mathrm{P} 4)$ (Fig. 2). In this case also, there was a progressive decrease in $E$. coli counts during storage until day 3, after which point regrowth of the pathogen was observed; however, the counts of the pathogen in the phage-treated beef (P12) remained consistently lower $\left(>2.0 \log _{10} \mathrm{CFU} / \mathrm{cm}^{2}, P<0.05\right)$ compared to the control (C12). Re-growth of Listeria monocytogenes on phage-treated roast beef and cooked turkey during storage has also been reported by Chibeu et al. (2013). The re-growth of E. coli observed in this study could be attributed to the inability of phage to reach all bacterial targets in the food matrix, resulting in E. coli multiplying in hard to reach protected areas (Guenther et al., 2012). Liu et al. (2015) treated beef with individual phages as well as a bacteriophage cocktail and found similar reductions (also using a virucide in their enumeration process) in the E. coli 0157 counts after $24 \mathrm{~h}$ and 3 days storage at $4^{\circ} \mathrm{C}$. They also stored samples at abuse temperatures, however due to the short duration of storage (6 h) and much higher storage temperatures $\left(22\right.$ and $\left.37^{\circ} \mathrm{C}\right)$ results are not comparable with this study. The results obtained indicate that refrigeration at $4^{\circ} \mathrm{C}$ did not prevent infection, 
although the low temperature probably prolonged the phage latent period and thus time to bacterial lysis (Ly-Chatain et al., 2014). It is noteworthy that inactivation of E. coli 0157 increased with storage temperature. Higher inactivation at higher temperatures was also observed in previous studies on leafy vegetables (Viazis et al., 2011). In conclusion, this study showed that the EcoShield ${ }^{\mathrm{TM}}$ phage cocktail could potentially be used as a hurdle to enhance the safety of raw beef in relation to E. coli 0157 .

\subsection{Natural interventions}

Washing with water is the first step in sanitation of many food commodities and is most commonly used to remove microorganisms and soil and other particles. Water washing alone was able to remove approx. $0.26-0.40 \log _{10}$ E. coli CFU/g. The wine vinegar used undiluted in the present study contained $6 \%$ (vol/vol) acetic acid. Preliminary trials showed that vinegar caused darkening of the meat when no water rinsing was applied after treatment (data not shown). Thus, a rinsing step for $30 \mathrm{sec}$ in sterile water was considered necessary following vinegar washing. Washing with vinegar resulted in a significant reduction in E. coli counts (Fig. 3). Immediately after washing a reduction of $0.98 \log _{10} \mathrm{CFU} / \mathrm{g}$ was achieved (P $<0.05)$ compared to the untreated control. Pathogen reductions were significantly higher compared to those caused by water washing alone throughout storage $(P<0.05)$. Interestingly, even after the water rinsing step, the vinegar treatment resulted in residual antimicrobial activity which was evident from the declining $E$. coli population during storage. The reduction during storage combined with the immediate reduction in viable $E$. coli resulted in an overall reduction in E. coli of $1.51 \log _{10}$ CFU/g after 7 days. A study by Harris et al. (2006) showed a $2.5 \log _{10}$ reduction for $E$. coli O157:H7 after spraying with $2 \%$ acetic acid with the effect remaining over time in refrigerated and frozen storage. Harris et al. (2012) investigated the effect of sterile water and $2 \%$ acetic acid on the levels of $E$. coli $0157: \mathrm{H} 7$ in beef in a simulated commercial processing environment. All treatments reduced the E. coli $0157: \mathrm{H} 7$ load by around $0.5 \log _{10}$ after $24 \mathrm{~h}$ in ground beef (not beef cuts, as in this study). According to Carpenter et al. (2010), $2 \%$ acetic acid did not show a 
high decontamination capacity compared to water wash but was able to prevent the growth of $E$. coli $\mathrm{O} 157: \mathrm{H} 7$ on beef. Therefore, results show that vinegar washing appears, even including a rinsing step to avoid beef darkening, to be an effective way to reduce the levels of $E$. coli immediately, as well as during subsequent storage, in beef.

Lactic acid is an organic acid that has received GRAS (Generally Recognized as Safe) status and can be used for the removal of surface decontamination in beef carcasses (EFSA 2011). Preliminary trials were conducted to identify the most appropriate lactic acid concentration for beef application (data not shown). A $5 \%$ lactic acid concentration was selected for subsequent experiments. Beef washing in a lactic acid solution for 5 min with a subsequent water rinsing for $30 \mathrm{~s}$ reduced $E$. coli by $1.10 \log _{10} C F U / g(P<0.05)$, whereas during 7 days of storage the pathogen gradually reduced to give an overall $2.22 \log _{10} \mathrm{CFU} / \mathrm{g}$ reduction (Fig. 3) compared to the control. E. coli counts for the water wash were significantly higher than the lactic acid treated samples throughout storage. The decontamination efficiency of lactic acid has been found to be influenced by a number of factors, e.g. acid concentration, volume used, nature of treated surface, application method and level of contamination (Youssef et al., 2012). In order to explore if the rinsing step may have had a quenching effect on the antimicrobial activity the lactic acid intervention study was also performed without incorporating a rinsing step (Fig. 3). Lactic acid resulted in a $1.19 \log _{10}$ CFU/g reduction in E. coli counts immediately after the 5 min treatment and reached an overall reduction of $2.74 \log _{10} \mathrm{CFU} / \mathrm{g}$ at the end of storage compared to the control. The counts of the lactic acid treatment were always significantly lower compared to the water wash $(P<0.05)$. There was a more pronounced progressive reduction of the pathogen counts during the first 3 days of storage after which pathogen levels remained relatively similar (no significant difference between day 3, 5 and 7). When compared to lactic acid plus rinsing (Fig. 3), the absence of a rinsing step led to a greater reduction in pathogen counts, after day 1 . The additional reduction achieved was in the range of $0.30-0.75 \log _{10}$ CFU/g during storage. Previous studies have shown that lactic acid (1-4\%) applied to beef can significantly reduce populations of E. coli (Dorsa et al., 1997; Castillo et al., 
2001). Harris et al. (2006) reported a $1.5 \log _{10} \mathrm{CFU} / \mathrm{g}$ reduction for E. coli O157:H7 could be achieved after spraying with lactic acid (4\%). Youssef et al. (2012) also found that treating beef cuts or trimmings with $5 \%$ lactic acid could reduce numbers of $E$. coli by $0.5-1 \log _{10}$ $\mathrm{CFU} / \mathrm{cm}^{2}$.

Nisin is a well-known bacteriocin, which also has GRAS status and is commercially used in the food industry to extend shelf-life and enhance food safety (Abdollahzadeh et al. 2014). When the nisin wash $(1000 \mathrm{IU} / \mathrm{ml})$ was applied alone, no significant reduction in $E$. coli counts on beef samples was achieved compared with water wash $(P<0.05)$. This was not unexpected since nisin is effective against Gram positive bacteria such as Brochothrix thermosphacta, Clostridium botulinum, Staphylococcus aureus, Listeria innocua or Listeria monocytogenes (Mustapha et al. 2002), and not necessarily Gram negative bacteria like E. coli. However, studies have shown that if nisin is combined with other hurdles, such as essential oils or chelators, it can be effective against E. coli (Fang and Tsai 2003; Solomakos et al. 2008). When a nisin wash $(1000 \mathrm{IU} / \mathrm{ml})$ was applied subsequent to a $5 \%$ lactic acid wash, followed by a $30 \mathrm{~s}$ water rinse, no additive or synergistic antimicrobial effects were observed immediately after treatment or during storage $(P>0.05)($ Fig. 3). Statistical analysis showed that the $5 \%$ lactic acid treatment and the lactic acid/nisin treatment did not differ significantly at any point during storage, revealing that the combination of lactic acid $(5 \%)$ and nisin $(1000 \mathrm{IU} / \mathrm{ml})$ does not result in enhanced effectiveness against $E$. coli. Mustapha et al. (2002) treated raw beef with lactic acid (2\%) alone and in combination with nisin (200 $\mathrm{IU} / \mathrm{ml}$ ) and they also found that nisin does not contribute to any additional antimicrobial effect compared to lactic acid alone against $E$. coli. In the present study higher concentrations of both lactic acid (5\%) and nisin were used $(1000 \mathrm{lU} / \mathrm{ml})$ but nevertheless it still did not result in any increase in effectiveness against $E$. coli.

Lactoferrin is an iron-binding antimicrobial glycoprotein that is found in milk and other mammalian exocrine secretions (Ye et al., 2000; Steijns and van Hooijdonk, 2000). The effect of lactoferrin $(0.5 \mathrm{mg} / \mathrm{ml})$ wash alone or in conjunction with nisin was studied. This concentration of lactoferrin was chosen as it has been previously reported that, under in 
vitro conditions, this concentration can impart a bactericidal effect (Murdock et al., 2007).

449 Results showed that there were no significant $(P>0.05)$ difference in reductions of $E$. coli 450 between water washing and lactoferrin wash (data not shown); reductions for water and lactoferrin were 0.26-0.42 and $0.35-0.46 \log _{10} \mathrm{CFU} / \mathrm{g}$, respectively, during storage. Our results are in agreement with the study of Del Olmo et al. (2012) who showed that lactoferrin $(0.5 \mathrm{mg} / \mathrm{ml})$ was not able to significantly reduce the counts of $E$. coli 0157 inoculated onto chicken fillets. Bravo et al. (2014) also found that lactoferrin alone applied to beef carpaccio was not able to reduce the counts of L. monocytogenes, Salmonella Enteritidis or $E$. coli 0157 . Since a study by Murdock et al. (2007) demonstrated that lactoferrin $(0.5 \mathrm{mg} / \mathrm{ml})$ and nisin $(250 \mathrm{IU} / \mathrm{ml})$ acted synergistically against $E$. coli $\mathrm{O} 157$ in vitro, lactoferrin was also evaluated in combination with a nisin wash $(1000 \mathrm{IU} / \mathrm{ml})$ in this study, to explore if any increase in effectiveness occurred for beef decontamination. In this case also there was no increase in the effectiveness, with the lactoferrin/nisin treatment achieving a similar reduction (0.30 $-0.49 \log _{10}$ CFU/g) to the water wash. The present study shows that the bactericidal effect of lactoferrin declines substantially when used for beef and that use of lactoferrin in conjunction with nisin does not offer any benefit under the applied conditions.

Plant essential oils, especially those from thyme, oregano, and clove, have strong antimicrobial effects. However, it has been shown that the effectiveness of essential oils is partially inhibited when applied to foods (Burt, 2004; Baranauskiene et al., 2006). The water insoluble nature of essential oils, as well as interaction with food components, can reduce their antimicrobial effects (Shah et al., 2012; Bhargava et al., 2015). Encapsulation of essential oils in nanoemulsions constitutes an alternative strategy to improve their antimicrobial efficiency in foods, by protecting them from interaction with food constituents and increasing their solubility, thus allowing a higher mass transfer of EO to the cell membranes of foodborne pathogens. The effect of two different EO nanoemulsions plus a water rinsing step on E. coli counts on beef are presented in Figure 4. In this case a buffer 474 wash was performed instead of a water wash in order to investigate if the lower $\mathrm{pH}$ of the buffer ( $\mathrm{pH}$ 3.5) used to prepare the EO nanoemulsions had any effect on $E$. coli survival. The 
reduction in $E$. coli counts achieved after the buffer wash were in the range of $0.30-0.51 \log _{10}$

477 CFU/g during storage, thus demonstrating no additional effect compared to the water wash employed for the other interventions. After initial preparation, the nanoemulsions were diluted 5-fold to avoid droplet size increase (Landry et al., 2014). After this 5-fold dilution, the nanoemulsions had a concentration of $8000 \mathrm{ppm}$ of either carvacrol or thyme. The carvacrol and thyme EO nanoemulsions prepared by spontaneous emulsification had an average particle size of 100 and $60 \mathrm{~nm}$, respectively, with a polydispersity index of $0.20-0.28$, measured by light scattering. The carvacrol nanoemulsion resulted in a significant reduction $(P<0.05)$ of $1.13 \log _{10} \mathrm{CFU} / \mathrm{g}$ compared to control immediately after treatment. A similar significant reduction was achieved by the thyme EO wash $\left(1.09 \log _{10}\right.$ CFU/g) immediately after the treatment. Both nanoemulsions also showed similar overall reductions by the end of storage (1.41 and $1.36 \log _{10} \mathrm{CFU} / \mathrm{g}$ for carvacrol and thyme EO, respectively). Statistical analysis showed that the counts of $E$. coli between the two nanoemulsion treatments did not membrane leading to the release of cell components, such as carbohydrates, proteins, DNA, and potassium ions (Burt, 2004; Moghimi et al., 2016). To the best of our knowledge this is the first study where nanoemulsions were applied to beef to combat $E$. coli contamination. to Landry et al. (2015), carvacrol nanoemulsion (4000 ppm and $8000 \mathrm{ppm}$ ) wash of radish and broccoli seeds reduced E. coli 0157 counts by $2-3 \log _{10} \mathrm{CFU} / \mathrm{g}$ after a $60 \mathrm{~min}$ treatment. Nanoemulsified thyme oil has also been demonstrated to result in significant reductions of $E$. coli (after 4 and $8 \mathrm{~h}$ ) in $2 \%$ reduced fat milk and has also been found to be more effective than free thyme oil (Xue et al., 2015). Moghimi et al. (2016) also found that 
thyme essential oil nanoemulsions (diameter $\sim 150 \mathrm{~nm}$ ) have high antibacterial activity against $E$. coli in vitro. Furthermore, the susceptibility of bacteria to essential oils has been shown to be dependent on the $\mathrm{pH}$ of the treatment (Shah et al., 2012). The nanoemulsions used in this study had a low $\mathrm{pH}$ (3.5), due to the sodium citrate buffer used to prepare them. The antimicrobial effect they imparted on E. coli could be due to combined low pH stress and the antimicrobial effects of carvarcol or thyme EO.

Nanoemulsion washes were also applied without the rinsing step. Carvacrol and thyme EO nanoemulsion showed significant reductions $(P<0.05)$ of 0.92 and $0.86 \log _{10} \mathrm{CFU} / \mathrm{g}$ after the 5 min treatment and 1.79 and $1.64 \log _{10}$ CFU/g, respectively, at the end of storage compared to the control. In this case also, no significant differences $(P>0.05)$ were observed in the effectiveness of the two nanoemulsions. The absence of a rinsing step led to a further reduction in the pathogen counts at day 1 , after which counts did not differ significantly between storage days (day $1 \mathrm{v}$ day 7 ). It also led to moderately greater reductions compared to when the rinsing step was included.

Although, there was an increase in nanoemulsion effectiveness in the absence of the rinsing step, the reduction obtained in this study was lower compared to other studies in other food matrices. This could possibly be explained by the different surface topography of the beef meat (e.g. surface roughness, crevices) which could allow bacteria to avoid contact with the nanoemulsions. Another explanation for the lower reductions would be the presence of higher amounts of organic load on the meat which could lead to loss of nanoemulsion effectiveness (Landry et al., 2015). Even though a high quantity of the essential oils was loaded into the nanoemulsions, the exposure time adopted was significantly shorter compared to previous studies on the same essential oils. The shorter exposure time would increase the applicability of this intervention and reduce the possibility of changes in the organoleptic characteristics of the meat; however further studies would be needed to prove this. Although less pronounced for nanoemulsions, the increased effectiveness observed for both lactic acid and nanoemulsions indicate the quenching effect that rinsing has on the antimicrobial activity of these two interventions. 


\section{Conclusion}

534 This study has identified several effective physical, biological and natural control 535 interventions to reduce pathogenic E. coli on beef - cold plasma treatment, application of a 536 phage cocktail, and use of vinegar, $5 \%$ lactic acid, and carvacrol and thyme oil 537 nanoemulsions - that could potentially find application in the beef industry. Other 538 interventions studied, namely silver-containing packaging, ozone applied in gaseous form, 539 and lactoferrin and nisin, even when applied in combination, did not demonstrate useful 540 reductions in pathogenic $E$. coli numbers. Further research would be needed to assess the 541 impact of the effective E. coli control interventions on the quality and sensory properties of 542 beef, as they could potentially impact consumer acceptance. Any potential effect of these 543 interventions on the virulence of surviving pathogenic E. coli 0157 cells should also be 544 evaluated.

\section{Acknowledgements}

This study was funded by Rangeland Foods, Lough Egish, Castleblayney, County Monaghan, Republic of Ireland. We would like to thank Dr Eugene Carmichael for technical assistance with the dynamic light scattering measurements.

\section{References}

Abdollahzadeh, E., Rezaei, M., Hosseini, H., 2014. Antibacterial activity of plant essential oils and extracts: The role of thyme essential oil, nisin, and their combination to control Listeria monocytogenes inoculated in minced fish meat. Food Cont. 35, 177-183.

Alkawareek, M.Y., Algwari, Q.T., Laverty, G., Gorman, S.P., Graham, W.G., O'Connell, D. and Gilmore, B.F., 2012. Eradication of Pseudomonas aeruginosa biofilms by atmospheric pressure non-thermal plasma. PLoS One 7, e44289. 
560

Arthur, T.M., Wheeler, T.L., Shackelford, S.D., Bosilevac, J.M., Nou, X., Koohmaraie, M., 2005. Effects of low-dose, low-penetration electron beam irradiation of chilled beef carcass surface cuts on Escherichia coli 0157: $\mathrm{H} 7$ and meat quality. J. Food Prot. 68, $666-672$.

Azlin-Hasim, S., Cruz-Romero, M. C., Morris, M. A., Cummins, E., Kerry, J.P. 2015. Effects of a combination of antimicrobial silver low density polyethylene nanocomposite films and modified atmosphere packaging on the shelf life of chicken breast fillets. Food Pack. Shelf Life, 26-35.

Baranauskiene, R., Venskutonis, P.R., Dewettinck, K., Verhe, R., 2006. Properties of oregano (Origanum vulgare L.), citronella (Cymbopogon nardus G.) and marjoram (Majorana hortensis L.) flavors encapsulated into milk protein-based matrices. Food Res. Int. 39, 413-425.

Bhargava, K., Conti, D. S., da Rocha, S. R., Zhang, Y. 2015. Application of an oregano oil nanoemulsion to the control of foodborne bacteria on fresh lettuce. Food Microbiol. 47, 69-73.

Boziaris, I.S., Nychas, G.J., 2006. Effect of nisin on growth boundaries of Listeria monocytogenes Scott $\mathrm{A}$, at various temperatures, $\mathrm{pH}$ and water activities. Food Microbiol. 23, 779-784.

Bravo, D., de Alba, M., Medina, M., 2014. Combined treatments of high-pressure with the lactoperoxidase system or lactoferrin on the inactivation of Listeria monocytogenes, Salmonella Enteritidis and Escherichia coli $0157: \mathrm{H} 7$ in beef carpaccio. Food Microbiol. 41, 27-32.

Burt, S., 2004. Essential oils: their antibacterial properties and potential applications in foods-a review. Int. J. Food Microbiol. 94, 223-253.

Chagnot, C., Agus, A., Renier, S., Peyrin, F., Talon, R., Astruc, T., Desvaux, M., 2013. In vitro colonization of the muscle extracellular matrix components by Escherichia coli 0157:H7: the influence of growth medium, temperature and $\mathrm{pH}$ on initial adhesion and induction of biofilm formation by collagens I and III. PLOS One 8(3): e59386. 
Chang, Y., McLandsborough, L., McClements, D.J., 2013. Physicochemical properties and antimicrobial efficacy of carvacrol nanoemulsions formed by spontaneous emulsification. J. Agric. Food Chem. 61, 8906-8913.

Chibeu, A., Agius, L., Gao, A., Sabour, P.M., Kropinski, A.M., Balamurugan, S., 2013. Efficacy of a bacterophage LISTEX ${ }^{\mathrm{TM}} \mathrm{P} 100$ combined with chemical antimicrobials in reducing Listeria monocytogenes in cooked turkey and roast beef. Int. J. Food Microbiol. 167, 208-214.

Chien, S.-Y., Sheen, S., Sommers, C.H., Sheen, L.-Y., 2016. Modeling the inactivation of intestinal pathogenic Escherichia coli $\mathrm{O} 157: \mathrm{H} 7$ and uropathogenic $E$. coli in ground chicken by high pressure processing and thymol. Front Microbiol. 7, 920.

Coll Cárdenas, F.C., Andrés, S., Giannuzzi, L., Zaritzky, N., 2011. Antimicrobial action and effects on beef quality attributes of a gaseous ozone treatment at refrigeration temperatures. Food Cont. 22, 1442-1447.

Costa, C., Conte, A., Buonocore, G.G., Del Nobile, M.A., 2011. Antimicrobial silvermontmorillonite nanoparticles to prolong the shelf life of fresh fruit salad. Int. J. Food Microbiol. 148, 164-7.

Damm, C., Munstedt, H., Rosch, A., 2008. The antimicrobial efficacy of polyamide 6/silvernano- and microcomposites. Mat. Chem. Phys. 108, 61-6.

Del Olmo, A., Calzada, J., Nuñez, M., 2012. Effect of lactoferrin and its derivatives, high hydrostatic pressure, and their combinations, on Escherichia coli O157:H7 and Pseudomonas fluorescens in chicken filets. Innov. Food Sci. Emerg. Technol. 13, 51-56.

Dirks, B.P., Dobrynin, D., Fridman, G., Mukhin, Y., Fridman, A., Quinlan, J.J., 2012. Treatment of raw poultry with nonthermal dielectric barrier discharge plasma to reduce Campylobacter jejuni and Salmonella enterica. J. Food Prot. 75, 22-28.

Dorsa, W.J., Cutter, C.N., Siragusa, G.R., 1997. Effects of acetic acid, lactic acid and trisodium phosphate on the microflora of refrigerated beef carcass surface tissue inoculated with Escherichia coli O157: H7, Listeria innocua, and Clostridium sporogenes. J. Food Prot. 60, 619-624. 
616 European Commission, 2010. The Consumer Markets Scoreboard. Making Markets Work

617 for Consumers (4th edition). Luxembourg: Directorate-General for Health \& Consumers.

618 http://ec.europa.eu/consumers/consumer evidence/consumer scoreboards/4 edition/doc

619 s/cms 4 en.pdf. Accessed 15 December 2017.

620 European Food Safety Authority (2011). Scientific opinion on the evaluation of the safety and

621 efficacy of lactic acid for the removal of microbial surface contamination of beef carcasses, cuts and trimmings. EFSA J. 9 (7), 2317.

623 European Commission, 2013. Regulation (EC) No 101/2013 of the European Parliament and of the Council of 4 February 2013 Concerning the use of lactic acid to reduce microbiological surface contamination on bovine carcasses. Off. J. Eur. Union 9, 20112013.

627 Fang, T.J., Tsai, H.C., 2003. Growth patterns of Escherichia coli O157: H7 in ground beef treated with nisin, chelators, organic acids and their combinations immobilized in calcium alginate gels. Food Microbiol. 20, 243-253.

Food Standards Agency, 2014. E. coli O157 control of cross contamination guidance for food business operators and local authorities. Available at: http://www.food.gov.uk/sites/default/files/ecoli-cross-contamination-guidance.pdf

634 Greene A.K., Guzel-Seydim Z.B., Seydim A.C., 2012. Chemical and physical properties of ozone, in: O'Donnell C., Tiwari B. K., Cullen P. J., Rice R. G., (Eds.). Ozone in Food Processing. Blackwell Publishing, Ltd., Oxford, pp. 19-32.

637 Guenther, S., Herzig, O., Fieseler, L., Klumpp, J., Loessner, M.J., 2012. Biocontrol of 638 Salmonella typhimurium in RTE foods with the virulent bacteriophage FO1-E2. Int. J. $639 \quad$ Food Microbiol. 154, 66-72

640 Han, L., Patil, S., Boehm, D., Milosavljević, V., Cullen, P. J., Bourke, P., 2016. Mechanisms 641 of inactivation by high-voltage atmospheric cold plasma differ for Escherichia coli and Staphylococcus aureus. Appl. Environ. Microbiol. 82, 450-458. 
Harris, D., Brashears, M.M., Garmyn, A.J., Brooks, J.C., Miller, M.F., 2012. Microbiological and organoleptic characteristics of beef trim and ground beef treated with acetic acid, lactic acid, acidified sodium chlorite, or sterile water in a simulated commercial processing environment to reduce Escherichia coli O157: H7 and Salmonella. Meat Sci. 90, 783-788.

Hsu, H., Sheen, S., Sites, J., Cassidy, J., Scullen, B., Sommers, C., 2015. Effect of high pressure processing on the survival of Shiga Toxin-producing Escherichia coli (Big Six vs. O157: H7) in ground beef. Food Microbiol. 48, 1-7.

Incoronato, A.L., Conte, A., Buonocore, G.G., Del Nobile, M.A. 2011. Agar hydrogel with silver nanoparticles to prolong the shelf life of Fior di Latte cheese. J. Dairy Sci. 94, $1697-704$.

Jamalludeen, N., Jonson, R.P., Friendship, R., Kropinski, A.M., Lingohr, E.J., Gyles, C.L. (2007). Isolation and characterization of nine bacteriophages that lyse 0149 enterotoxigenic Escherichia coli. Vet. Microbiol. 124, 47-57.

Jassim, S.A.A., Denyer, S.P., Stewart, G.S.A.B., 1998. Antiviral or antifungal composition comprising an extract of pomegranate rind or other plants and method of use. U.S Patent 5840308.

Khadre, M.A., Yousef, A.E., Kim, J.G., 2001. Microbiological aspects of ozone applications in food: a review. J. Food Sci. 66, 1242-1252.

Kim, J.S., Lee, E.J., Choi, E.H., Kim, Y.J., 2014. Inactivation of Staphylococcus aureus on the beef jerky by radio-frequency atmospheric pressure plasma discharge treatment. Innov. Food Sci. Emerg. Technol. 22, 124-130.

Kim, H.-J. Yong, H.I., Park, S., Choe, W., Jo, C., 2013. Effects of dielectric barrier discharge plasma on pathogen inactivation and the physicochemical and sensory characteristics of pork loin. Curr. Appl. Phys. 13, 1420-1425.

Kudva, I.T., Jelacic, S., Tarr, P.I., Youderian, P., Hovde, C.J., 1999. Biocontrol of Escherichia coli 0157 with 0157-specific bacteriophages. Appl. Environ. Microbiol. 65, 3767-3773. 
670 Landry, K.S., Chang, Y., McClements, D.J., McLandsborough, L. 2014. Effectiveness of a 671 novel spontaneous carvacrol nanoemulsion against Salmonella enterica Enteritidis and 672 Escherichia coli O157: H7 on contaminated mung bean and alfalfa seeds. Int. J. Food 673 Microbiol. 187, 15-21.

674 Landry, K.S., Micheli, S., McClements, D.J., McLandsborough, L. 2015. Effectiveness of a 675 spontaneous carvacrol nanoemulsion against Salmonella enterica Enteritidis and 676 Escherichia coli O157:H7 on contaminated broccoli and radish seeds. Food Microbiol. 51, $677 \quad 10-17$.

678 Liu, H., Niu, Y.D., Meng, R., Wang, J., Li, J., Johnson, R.P., McAllister, T.A., Stanford, K., 679 2015. Control of Escherichia coli O157 on beef at 37, 22 and $4^{\circ} \mathrm{C}$ by T5-, T1-, T4-and O1680 like bacteriophages. Food Microbiol. 51, 69-73.

681 Ly-Chatain, M.H., 2014. The factors affecting effectiveness of treatment in phages 682 therapy. Front. Microbiol. 5, 51.

McCann, M.S., McGovern, A.C., McDowell, D.A., Blair, I.S., Sheridan, J.J., 2006. Surface decontamination of beef inoculated with Salmonella Typhimurium DT104 or Escherichia coli O157: H7 using dry air in a novel heat treatment apparatus. J. appl. Microbiol. 101, 1177-1187.

686

McMillin, K., Michel, M., 2000. Reduction of E. coli in ground beef with gaseous ozone. 687 Louisiana Agriculture 43, 35.

Min, S.C., Roh, S.H., Niemira, B.A., Sites, J.E., Boyd, G., Lacombe, A. 2016. Dielectric 689 barrier discharge atmospheric cold plasma inhibits Escherichia coli O157: H7,

Misra, N.N., Jo, C., 2017. Applications of cold plasma technology for microbiological safety 693 in meat industry. Trends Food Sci. Technol. 64, 74-86.

Moghimi, R., Ghaderi, L., Rafati, H., Aliahmadi, A., McClements, D.J. 2016. Superior 695 antibacterial activity of nanoemulsion of Thymus daenensis essential oil against $E$. coli. Food Chem. 194, 410-415. 
697

698

699

700

701

702

703

704

705

706

707

708

709

710

711

712

713

714

715

716

717

718

719

720

721

722

723

Mohan, A., Pohlman, F.W., 2016. Role of organic acids and peroxyacetic acid as antimicrobial intervention for controlling Escherichia coli $0157: \mathrm{H} 7$ on beef trimmings. LWT - Food Sci. Technol. 65, 868-873.

Murdock, C.A., Cleveland, J., Matthews, K.R., Chikindas, M.L. 2007. The synergistic effect of nisin and lactoferrin on the inhibition of Listeria monocytogenes and Escherichia coli O157: H7. Lett. appl. Microbiol. 44, 255-261.

Mustapha, A., Ariyapitipun, T., Clarke, A.D., 2002. Survival of Escherichia coli 0157:H7 on vacuum-packaged raw beef treated with polylactic acid, lactic acid and Nisin. J. Food Sci. $67,262-267$.

Patterson M.F., 2005. Microbiology of pressure treated foods. J. Appl. Microbiol. 98, 14001409.

Rajkowski, K.T., Marmer, B.S., 1995. Growth of Escherichia coli 0157:H7 at fluctuating incubation temperatures. J. Food Prot. 58, 13071313.

Poimenidou, S.V., Bikouli, V.C., Gardeli, C., Mitsi, C., Tarantilis, P.A., Nychas, G.J. Skandamis, P.N., 2016. Effect of single or combined chemical and natural antimicrobial interventions on Escherichia coli O157: H7, total microbiota and color of packaged spinach and lettuce. Int. J. Food Microbiol. 220, 6-18.

Selma, M.V., Ibáñez, A.M., Allende, A., Cantwell, M., Suslow, T., 2008. Effect of gaseous ozone and hot water on microbial and sensory quality of cantaloupe and potential transference of Escherichia coli O157:H7 during cutting. Food Microbiol. 25, 162-168.

Shah, B., Davidson, P. M., \& Zhong, Q., 2012. Nanocapsular dispersion of thymol for enhanced dispersibility and increased antimicrobial effectiveness against Escherichia coli O157:H7 and Listeria monocytogenes in model food systems. Appl. Environ. Microbiol. 78, 8448-8453.

Sofos J.N., 2005. Improving the Safety of Fresh Meat. Woodhead Publishing in Food Science and Technology, CRC Press, New York. 
Solomakos, N., Govaris, A., Koidis, P., Botsoglou, N., 2008. The antimicrobial effect of thyme essential oil, nisin and their combination against Escherichia coli $\mathrm{O} 157: \mathrm{H} 7$ in minced beef during refrigerated storage. Meat Sci. 80, 159-166.

Steijns, J.M., Van Hooijdonk, A.C.M., 2000. Occurrence, structure, biochemical properties and technological characteristics of lactoferrin. Brit. J. Nutr. 84, 511-517.

Stratakos, A.C., Delgado-Pando, G., Linton, M., Patterson, M.F. and Koidis, A., 2015. Synergism between high-pressure processing and active packaging against Listeria monocytogenes in ready-to-eat chicken breast. Innov. Food Sci. Emerg. Technol. 27, 4147.

Ulbin-Figlewicz N., Jarmoluk, A., Marycz, K., 2015. Antimicrobial activity of low-pressure plasma treatment against selected foodborne bacteria and meat microbiota. Ann. Microbiol. 65, 1537-1546.

USDA Food Safety and Inspection Service (USDA-FSIS), 1996. Pathogen Reduction; Hazard Analysis and Critical Control Point (HACCP) Systems. 61 Federal Register. https://www.gpo.gov/fdsys/pkg/FR-1996-07-25/pdf/96-17837.pdf. Accessed 15 December 2017

USDA Food Safety and Inspection Service, 2015. Use of non-pathogenic Escherichia coli (E. coli) cultures as surrogate indicator organisms in validation studies. https://askfsis.custhelp.com/app/answers/detail/a id/1392/ /use-of-non-pathogenicescherichia-coli-\%28e.-coli\%29-cultures-as-surrogate. Accessed 15 December 2017.

Viazis, S., Akhtar, M., Feirtag, J., Diez-Gonzalez, F., 2011. Reduction of Escherichia coli O157: $\mathrm{H} 7$ viability on leafy green vegetables by treatment with a bacteriophage mixture and trans-cinnamaldehyde. Food Microbiol. 28, 149-157.

Wani, S., Maker, J.K., Thompson, J.R., Barnes, J., Singleton, I., 2015. Effect of ozone treatment on inactivation of Escherichia coli and Listeria sp. on spinach. Agriculture 5,155-169.

Wheeler, T.L., Kalchayanand, N., Bosilevac, J.M., 2014. Pre-and post-harvest interventions to reduce pathogen contamination in the US beef industry. Meat Sci. 98, 372-382. 
752 World Health Organisation, 2015. WHO's first ever global estimates of foodborne

753 diseases find children under 5 account for almost one third of deaths.

754 http://www.who.int/mediacentre/news/releases/2015/foodborne-disease-estimates/en/.

755 Accessed 15 December 2017.

756 Xue, J., Davidson, P.M., Zhong, Q., 2015. Antimicrobial activity of thyme oil co-

757 nanoemulsified with sodium caseinate and lecithin. Int. J. Food Microbiol. 210, 1-8.

758 Ye, X.Y., Wang, H.X., Liu, F., Ng, T.B., 2000. Ribonuclease, cell-free translation-inhibitory

759 and superoxide radical scavenging activities of the iron-binding protein lactoferrin from

760 bovine milk. Int. J. Biochem. C. Biol. 32, 235-241.

761 Youssef, M.K., Yang, X., Badoni, M., Gill, C.O., 2012. Effects of spray volume, type of 762 surface tissue and inoculum level on the survival of Escherichia coli on beef sprayed with $7635 \%$ lactic acid. Food Cont. 25, 717-722.

764 Ziuzina, D., Patil, S., Cullen, P.J., Keener, K.M., Bourke, P. 2012. Atmospheric cold plasma 765 inactivation of Escherichia coli in liquid media inside a sealed package. J. Appl. Microbiol. $766 \quad 114,778-787$. 
Table 1

769 Summary of natural interventions studied for control of pathogenic $E$. coli on raw beef.

\begin{tabular}{|c|c|c|c|}
\hline Intervention & Concentration & $\begin{array}{l}\text { Exposure time } \\
\text { (min) }\end{array}$ & Rinsing $^{a}$ \\
\hline Sterile water & - & 5 & - \\
\hline Vinegar ${ }^{b}$ & $6 \%$ acetic acid & 5 & Yes \\
\hline Lactic acid & $5 \%$ & 5 & Yes \\
\hline Lactic acid & $5 \%$ & 5 & No \\
\hline Nisin & $1000 \mathrm{IU} / \mathrm{ml}$ & 5 & Yes \\
\hline Lactic acid - Nisin & $5 \%-1000 \mathrm{IU} / \mathrm{ml}$ & 5 & Yes \\
\hline Lactoferrin & $0.5 \mathrm{mg} / \mathrm{ml}$ & 5 & Yes \\
\hline Lactoferrin - Nisin & $0.5 \mathrm{mg} / \mathrm{ml}-1000 \mathrm{IU} / \mathrm{ml}$ & 5 & Yes \\
\hline Carvacrol EO nanoemulsion & 8000 ppm & 5 & Yes \\
\hline Carvacrol EO nanoemulsion & 8000 ppm & 5 & No \\
\hline Thyme EO nanoemulsion & 8000 ppm & 5 & Yes \\
\hline Thyme EO nanoemulsion & 8000 ppm & 5 & No \\
\hline
\end{tabular}

${ }^{a}$ rinsing after intervention treatment in sterile water.

b Shop bought vinegar used without dilution; label indicated $6 \%$ acetic acid. 


\section{Figure legends}

782

783 Fig. 1. Effect of antimicriobial packaging (A) and cold plasma (2 and 5 min treatment) (B) on 784 levels of $E$. coli on artificially contaminated beef during storage at $4^{\circ} \mathrm{C}$. Each point is the 785 average of six replicates. Error bars represent \pm standard deviation.

786

787 Fig. 2. Effect of the EcoShield ${ }^{\mathrm{TM}}$ phage cocktail wash on numbers of E. coli on artificially 788 contaminated beef during storage at $4^{\circ} \mathrm{C}$ and $12^{\circ} \mathrm{C}$. (C4: control samples stored at $4^{\circ} \mathrm{C}$; P4: 789 phage treated samples stored at $4^{\circ} \mathrm{C}$; $\mathrm{C} 12$ : control samples stored at $12^{\circ} \mathrm{C}$; $\mathrm{P} 12$ : phage 790 treated samples stored at $12^{\circ} \mathrm{C}$ ). Each point is the average of six replicates. Error bars 791 represent \pm standard deviation.

792

793 Fig. 3. Effect of vinegar, lactic acid (with and without rinsing) (5\%), nisin (1000 IU/ml) alone 794 or in combination with lactic acid on the levels of E. coli on artificially contaminated beef 795 during storage at $4^{\circ} \mathrm{C}$. Each point is the average of six replicates. Error bars represent \pm 796 standard deviation.

797

798 Fig. 4. Effect of carvacrol and thyme essential oil (EO) nanoemulsions with and without 799 water rinsing (30 s) on levels of $E$. coli on artificially contaminated beef during storage at 800 $4^{\circ} \mathrm{C}$. Each point is the average of six replicates. Error bars represent \pm standard deviation. 
Fig. 1.

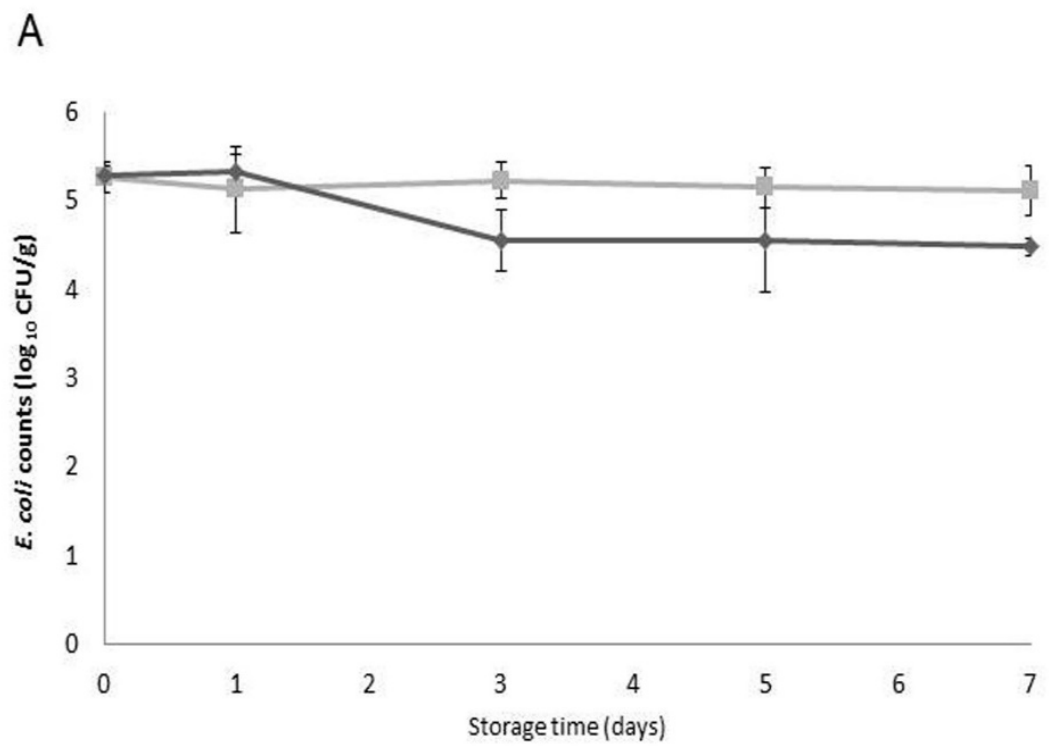

-Conventional packaging $\quad \sim$-Antimicrobial packaging

B

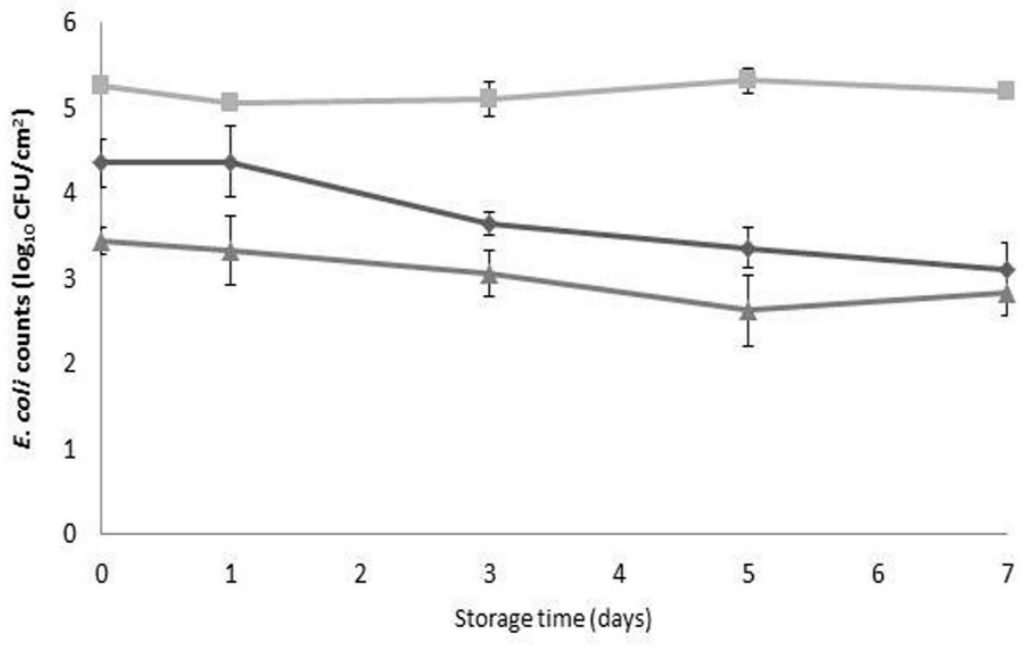

- Control $\quad-5$ min plasma treatment $\quad-2$ min plasma treatment 
Fig. 2.

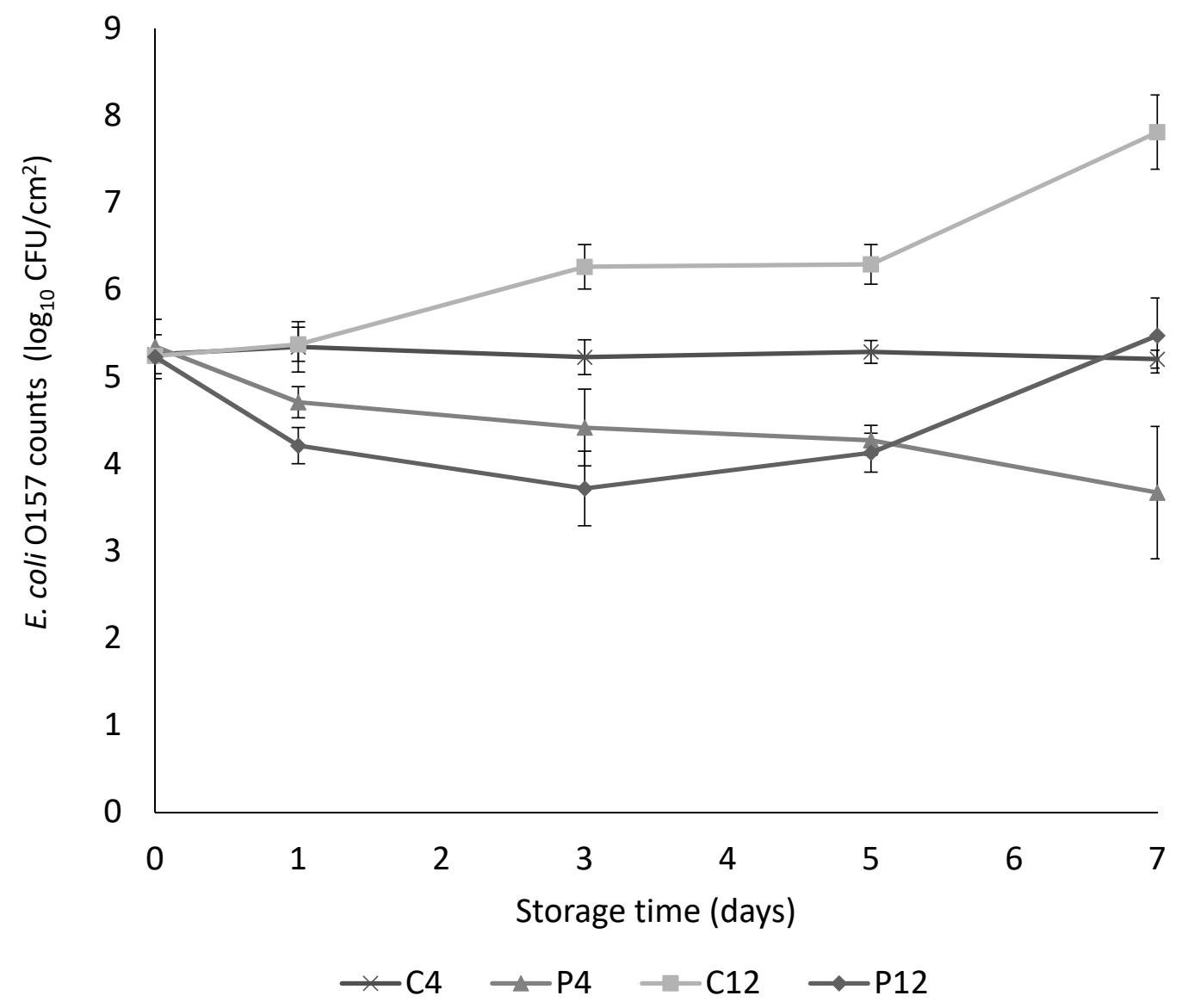


Fig. 3.

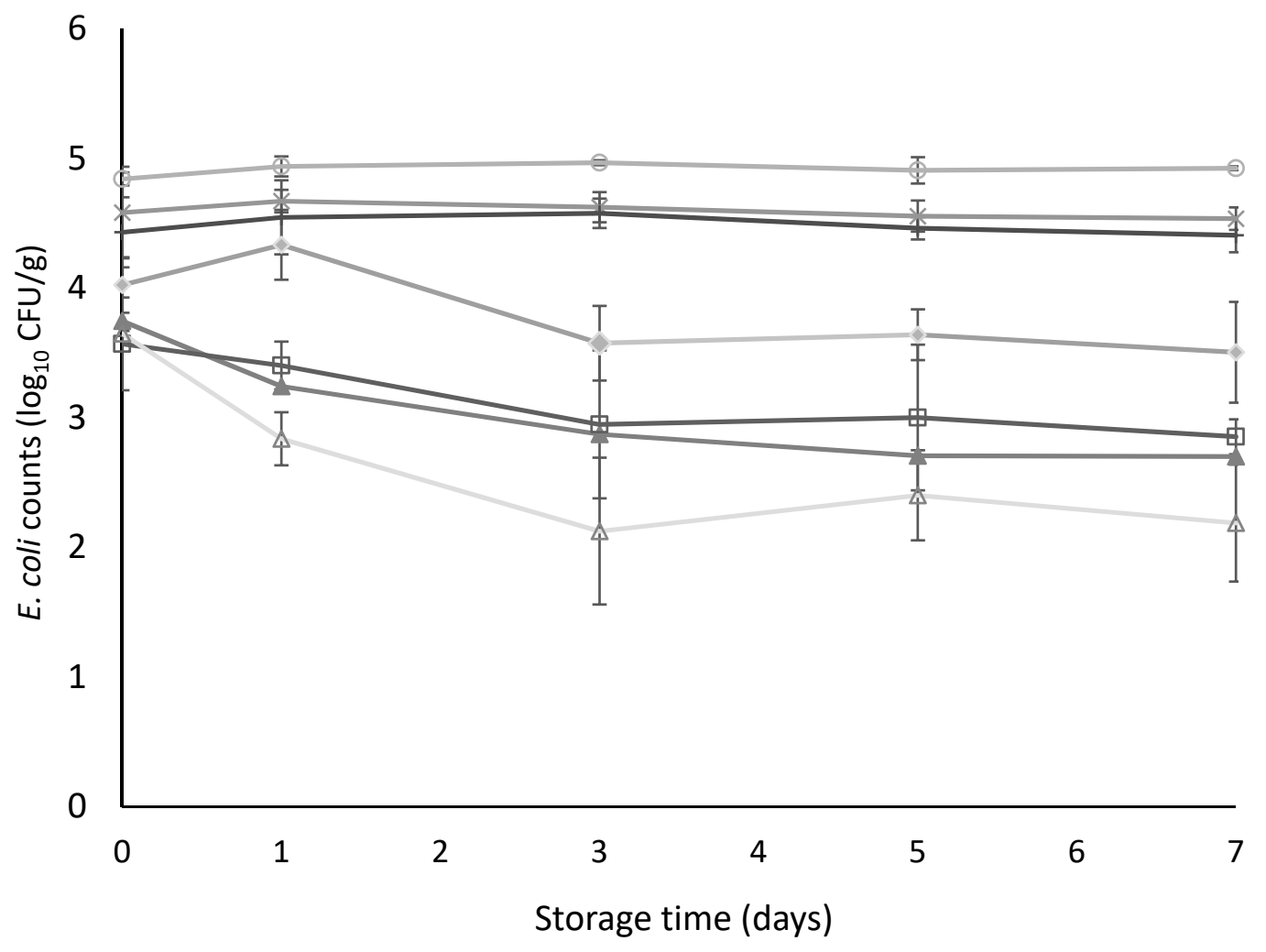

- Control
- Lactic acid (5\%)
+ Nisin
-- Vinegar

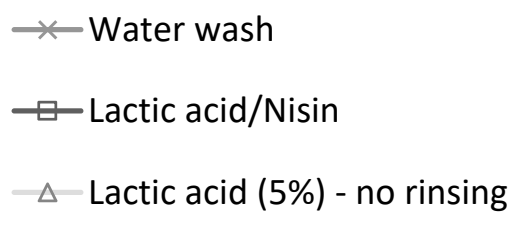




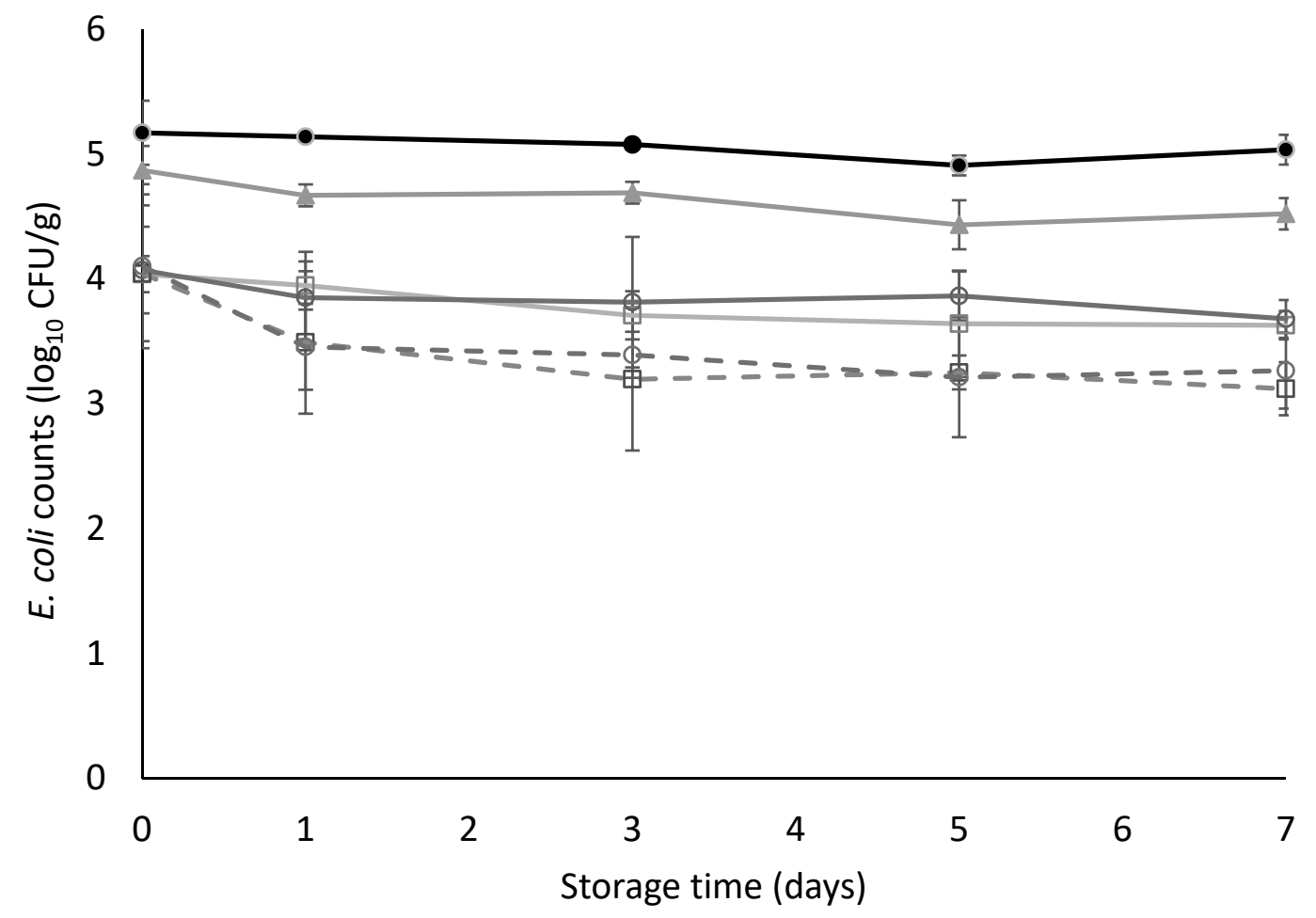

-0-Control

$\longrightarrow$ Buffer wash

$\square-$ Carvacrol nanoemulsion

- Thyme EO nanoemulsion

$-\boxminus-$ Carvacrol nanoemulsion w/o rinsing $-\ominus-$ Thyme EO nanoemulsion w/o rinsing 